Originalni naučni rad

\title{
Relacije Mračne tetrade, aleksitimije i distresa: analiza na nivou faceta, antagonističkog i agensnog faktora mračnih crta
}

Bojana M. Dinićø1 (D), Anđela Cmiljanić1 i Nikola Rokvić

${ }^{1}$ Odsek za psihologiju, Filozofski fakultet, Univerzitet u Novom Sadu

${ }^{2}$ Fakultet za pravne i poslovne studije dr Lazar Vrkatić, Univerzitet Union

\section{SAŽETAK}

Osnovni cilj ovog istraživanja je utvrđivanje relacija između crta Mračne tetrade i faktora aleksitimije i distresa, uzimajući u obzir multidimenzionalnu prirodu mračnih crta, kao i njihove antagonističke (maladaptivne) aspekte i aspekte delotvornosti ili agensne aspekte (adaptivnije aspekte). Dodatno, ispitana je medijatorska uloga faktora aleksitimije u odnosu između mračnih crta i distresa. Na uzorku od 355 ispitanika (71.3\% ženskog pola) iz opšte populacije, primenjeni su sledeći instrumenti: Toronto skala aleksitimije (TAS-21), Skala depresije, anksioznosti i stresa (DASS-21), Levensonova skala psihopatije (LSRP), Petofaktorski inventar makijavelizma (FFMI), Kratka verzija Petofaktorskog inventara narcizma (FFNI-SF) i Procena sadističke ličnosti (ASP). Rezultati pokazuju da facete mračnih crta i faktori aleksitimije dele $56 \%$ zajedničke varijanse, te da su dominantni prediktori aleksitimije sekundarna psihopatija u pozitivnom smeru i makijavelistička delotvornost u negativnom smeru, a potom i narcistički antagonizam i primarna psihopatija, oba u pozitivnom smeru. Rezultati pokazuju da faktor mračnih crta koji okuplja agensne karakteristike na pozitivnom polu ostvaruje veći i negativni doprinos u objašnjenju aleksitimije i distresa, u odnosu na faktor koji okuplja primarno antagonističke karakteristike. Mračnim crtama je najviše objašnjen faktor aleksitimije koji se odnosi na probleme u identifikaciji emocija, i ujedno je ovaj faktor jedini značajan 
medijator u predikciji distresa na osnovu skoro svih faceta i oba faktora Mračne tetrade. Naime, primarno antagonističke crte su pozitivno povezane sa distresom usled većeg deficita u identifikaciji emocija, dok su mračne crte koje se više odnose na delotovrnost negativno povezane sa distresom zbog manjih emocionalnih deficita.

Ključne reči: Mračna tetrada, Mračna trijada, antagonizam, delotvornost, aleksitimija, distres

UDK: 159.923 .072

DOI: 10.19090/pp.2021.3.329-364

Primljeno: 13.07.2021.

Primljena korekcija: 24.09.2021.

Prihvaćeno za štampu: 11.10.2021.

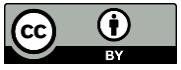

Copyright @ 2021 The Author(s).

This is an open access article distributed under the terms of the Creative Commons Attribution License, which permits unrestricted use, distribution, and reproduction in any medium, provided the original author and source are credited.

$\bowtie$ Corresponding author e-mail: bojana.dinic@ff.uns.ac.rs 


\section{Uvod}

U poslednjih 20-ak godina primetan je porast interesovanja kod istraživača za ispitivanje tzv. mračnih crta ličnosti koje se odnose na socijalno averzivne karakteristike (Dinić \& Jevremov, 2019). Paulhus i Williams (Paulhus \& Williams, 2002) su prvi predložili klaster tri mračne crte koji su nazvali Mračna trijada i koji obuhvata supkliničku psihopatiju, makijavelizam i supklinički narcizam. Psihopatija se odnosi na bezosećajnost i impulsivno ponašanje; makijavelizam na cinizam i manipulativno ponašanje u interpersonalnim odnosima; i narcizam se u okviru Mračne trijade uobičajeno istraživao kao grandiozni, agensni narcizam, odnosno kao doživljaj povlašćenosti i superiornosti u inteligenciji, različitim kompetencijama, fizičkoj privlačnosti itd. (više u Paulhus \& Williams, 2002). Ovaj set mračnih osobina naknadno je proširen dodavanjem svakodnevnog sadizma čineći Mračnu tetradu zajedno sa preostalim mračnim crtama (Chabrol et al., 2009). Sadizam se odnosi na uživanje u tuđem bolu, patnji i ponižavanju (Plouffe et al., 2017).

Crte Mračne trijade (videti meta-analizu Muris et al., 2017) i Mračne tetrade (Dinić et al., 2020a) povezuju se s negativnim ishodima mentalnog zdravlja, kao što su loše blagostanje, prisustvo psiholoških i somatskih simptoma, loše generalno i socijalno funkcionisanje. U novijim istraživanjima je pokazano da makijavelizam ostvaruje dosledne veze sa psihološkim distresom (anksioznošću, depresivnošću i stresom, videti Birkás et al., 2018; Mojsa-Kaja et al., 2021), psihopatija ili pozitivne (Mojsa-Kaja et al., 2021) ili neznačajne veze sa aspektima distresa (Birkás et al., 2018), dok narcizam ostvaruje nedosledne veze sa aspektima mentalnog zdravlja. $U$ jednoj metaanalizi narcizam nije ostvario značajne veze sa blagostanjem (Muris et al., 2017), ali u kasnijim istraživanjima ostvaruje pozitivnu vezu s blagostanjem (Dinić et al., 2020a; Kaufman et al., 2018) i negativnu sa distresom (Birkás et al., 2018), ali ima istraživanja u kojem je ostvario pozitivnu vezu sa distresom (Mojsa-Kaja et al., 2021). Ipak, postoji stanovište da je narcizam "najsvetlija” od svih mračnih crta (Rauthmann \& Kolar, 2012), te da sadrži i adaptivne aspekte. $\mathrm{O}$ adaptivnoj ulozi narcizma se govori i u sistematičnom prikazu u 
kojem je ukazano na to da pod određenim okolnostima grandiozni narcizam može doprineti rezilijentnosti i biti povezan sa pozitivnim zdravstvenim ishodima (Coleman et al., 2018). Sumirano, dok makijavelizam, psihopatija i sadizam pokazuju negativne veze sa indikatorima mentalnog zdravlja, neki aspekti narcizma mogu biti adaptivni tj. povezuju se sa pozitivnim ishodima mentalnog i fizičkog zdravlja. Treba napomenuti da se u prethodnim istraživanjima za procenu crta Mračne trijade koristio standardni instrumentarijum prema kome se npr. makijavelizam i narcizam sagledavaju kao jednodimenzionalni konstrukti.

Rezultati velikog broja istraživanja pokazali su da postoji značajna pozitivna povezanost među mračnim crtama, ali da su one ipak distinktivne dimenzije ličnosti (npr. Furnham et al., 2013). Ipak, sve mračne crte dele zajedničke karakteristike koje predstavljaju tzv. mračno jezgro/srž. Postoje različiti predlozi u vezi s tim šta čini mračno jezgro, ali kao najbolji kandidat za ono što čini srž mračnih crta može se izdvojiti bezosećajnost, odnosno emocionalni deficiti (Dinić et al., 2020b; 2021b; Paulhus, 2014).

Jedan od pokazatelja emocionalnih deficita je aleksitimija. Aleksitimija predstavlja klinički sindrom koji karakteriše nemogućnost osobe da prepozna i razume sopstvena osećanja, da razlikuje osećanja od telesnih senzacija ili emocionalnog uzbuđenja, te da reguliše i predoči okolini svoja emotivna stanja (Taylor, 2000). Prema Bagby-ju i sar. (Bagby et al., 1994), aleksitimija obuhvata tri faktora: 1) poteškoće u identifikovanju sopstvenih osećanja, 2) poteškoće u opisivanju sopstvenih osećanja, i 3) eksterno orijentisano mišljenje (praktičan način mišljenja, te umanjena sposobnost fantazije). lako je interesovanje za aleksitimiju počelo u kontekstu psihosomatskih oboljenja, dakle kliničke populacije, u okviru jedne pregledne studije je ukazano na to da je aleksitimija relativno česta karakteristika u opštoj populaciji (oko 10\%, prema Karukivi \& Saarijärvi, 2014), te da se distribuira normalno $u$ opštoj populaciji, pa se može smatrati i karakterisitkom ličnosti. Pored toga što se smatra osobinom ličnosti, aleksitimija ujedno sadrži i karakteristike stanja (Karukivi \& Saarijärvi, 2014). Naime, tri faktora aleksitimije pokazuju različiti stepen stabilnosti u longitudinalnim studijama i zavise od raspoloženja ili prisutnosti nekih 
simptoma (više u Karukivi \& Saarijärvi, 2014). Aleksitimija se povezuje s negativnim afektivitetom i opštim distresom (Cmiljanić i Rokvić, 2018; Nekouei et al., 2014), te depresijom i anksioznošću (Murphy et al., 2018), somatizacijom i mentalnim poremećajima kao što su depresija, anksiozni poremećaji, poremećaji ishrane i zloupotreba supstanci (više u preglednim studijama Karukivi \& Saarijärvi, 2014; Taylor \& Bagby, 2013). Upravo zbog nesposobnosti da identifikuju uzroke svojih emocije i da pronađu odgovarajuće reči kojima bi opisali svoja osećanja, osobe s višom aleksitimijom imaju poteškoće u socijalnim interakcijama (npr. Jordan \& Smith, 2017, pogledati i preglednu studiju Taylor \& Bagby, 2013). Generalno in karakteriše slaba emocionalna regulacija (Chen et al., 2011), zbog čega su i više sklone agresiji (Velotti et al., 2016).

Rezultati prethodnih istraživanja pokazuju da su faktori aleksitimije pozitivno i umereno povezani sa psihopatijom i makijavelizmom, dok su veze sa narcizmom nedosledne, te se u nekim istraživanjima dobija pozitivna (Jonason \& Krause, 2013), u nekim negativna veza (Cairncross et al., 2013), a u nekim neznačajna veza, mada kada se sagledaju veze na nivou faceta narcizma, postoji pozitivna veza sa faktorom poteškoća u identifikaciji osećanja (Schimmenti et al., 2019). Rezultati istraživanja koje je obuhvatilo samo ženske ispitanike pokazuje da je psihopatija pozitivno povezana sa svim faktorima aleksitimije, narcizam sa poteškoćama u identifikaciji osećanja, dok makijavelizam ne ostvaruje značajnu povezanost ni sa jednim aspektom (Garofalo et al., 2019). Dodatno, faktori aleksitimije su bili značajni medijatori između patoloških crta ličnosti s jedne strane i psihopatije i makijavelizma s druge strane (Garofalo et al., 2019). Kada se psihopatija sagleda kao multidimenzionalni konstrukt, većina istraživanja potvrđuje značajnu vezu između aleksitimije i sekundarne psihopatije, koju karakteriše impulsivnost i antisocijalno ponašanje (npr. Lander et al., 2012; Louth et al., 1998; Ridings \& Lutz-Zois, 2014), uključujući i rezultate nedavne metaanalitičke studije (Burghart \& Mier, 2021). S druge strane, veza između aleksitimije i primarne psihopatije, koju karakteriše emocionalna hladnoća i manipulativnost, generalno je niža (Burghart \& Mier, 2021). Pored toga, primarna psihopatija najviše korelira sa eksternim mišljenjem, a niže ili 
neznačajno sa preostala dva faktora aleksitimije (Lander et al., 2012; Takamatsu \& Takai, 2017). Međutim, u slučaju drugačijeg merenja prepoznavanja emocija dobijeno je da je samo primarna psihopatija značajan negativan prediktor prepoznavanja različitih emocija, ali ne i sekundarna, a pored nje se i narcizam izdvaja kao negativan prediktor (Puthillam et al., 2019). Treba pomenuti i studiju na uzorku zatvorenika u kojoj je dobijen obrnuti obrazac veza, tj. psihopatija je, iznenađujuće, negativno korelirala s faktorima aleksitimije (Pham et al., 2010). Ipak, većina studija govori o pozitivnoj vezi emocionalnih deficita i mračnih crta, posebno psihopatije, dok se suprotan obrazac veza može pripisati specifičnim uslovima (npr. zatvorsko okruženje).

S obzirom na to da su emocionalni deficiti sržna karakteristika mračnih crta, postavlja se pitanje kakva je njihova uloga u odnosu mračnih crta sa različitim indikatorima mentalnog zdravlja. S jedne strane, može se pretpostaviti da će emocionalni deficiti doprineti većoj učestalosti negativnih ishoda, odnosno da će adekvatno emocionalno funkcionisanje doprineti boljem mentalno zdravlju. Tako, pokazano je da emocionalna inteligencija moderira odnos između primarne psihopatije i sagorevanja, te na visokim skorovima na emocionalnoj inteligenciji, primarna psihopatija se povezuje s manjim sagorevanjem na poslu (Grover \& Furnham, 2021). Takođe, kognitivni aspekt empatije, koji se odnosi na nisku aleksitimiju, pokazao se kao značajan medijator u predikciji indirektne agresije na osnovu psihopatije i makijavelizma, te doprinosi manjoj agresiji (Heym et al., 2019).

$S$ druge strane, posmatrano iz evolucione perspektive, emocionalni deficiti poput aleksitimije mogu biti adaptivni pod određenim uslovima. Naime, osobe sa smanjenom empatijom i ograničenom sposobnošću ili motivacijom da okolini predoče svoja emotivna stanja mogu lakše da se upuste u ponašanja kroz koja vrše manipulaciju i iskorišćavanje drugih u cilju sopstvenog opstanka (Jonason \& Krause, 2013). Kako autori navode, previše utrošenog vremena na brigu vezanu za svoje ili tuđe emocije predstavlja prepreku za osobe sa mračnim odlikama jer in koči u njihovoj strategiji eksploatacije (Jonason \& Krause, 2013). U prethodnim istraživanjima se adaptivnost mračnih crta najviše ispitivala u kontekstu reproduktivnog 
uspeha (videti npr. pregledni rad Koehn et al., 2019). U ovom radu se ispituje njihova potencijalna adaptivna uloga u kontekstu mentalnog zdravlja. S obzirom na to, može se očekivati da će osobe s mračnim crtama imati dobiti od emocionalnih deficita, $\mathrm{tj}$. da će in karakterisati bolje mentalno zdravlje i manje distresa.

\section{Problem istraživanja}

Osnovni problem ovog istraživanja odnosi se na utvrđivanje relacija između crta Mračne tetrade i faktora aleksitimije i distresa, sagledavajući mračne crte kao multidimenzionalne konstrukte. $U$ prethodnim istraživanjima su mračne crte sagledavane kao jednodimenzionalne, uprkos preporukama da se tretiraju kao multidimenzionalni konstrukti budući da facete istog konstrukta mogu ostvariti suprotan obrazac veza sa određenim ishodima i ponašanjima (više u Miller et al., 2019). lako se emocionalni deficiti smatraju sržnom karakteristikom mračnih crta (npr. Dinić et al., 2020b; 2021b), prethodna istraživanja ukazuju na nedosledne veze aleksitimije sa narcizmom (npr. Cairncross et al., 2013; Jonason \& Krause, 2013). S obzirom na to da mračne crte mogu imati adaptivne i maladaptivne karakteristike (npr. Collison et al., 2018), multidimenzionalnim pristupom se može dobiti jasniji uvid $u$ njihovu funkcionalnost preko relacija sa aleksitimijom i negativnim ishodima mentalnog zdravlja. Može se očekivati da će aspekti pretežno maladaptivni aspekti mračnih crta koji se više povezuju s antagonizmom (primarna i sekundarna psihopatija, sadizam, antagonistički aspekt narcizma i makijavelizma) biti pozitivno povezani s aleksitimijom i distresom, dok će se aspekti mračnih crta koji se više povezuju s adaptivnim karakteristikama koje se odnose na agensni aspekt (agensni aspekt makijavelizma i narcizma) pokazati obrnuti obrazac veza.

Pored toga, u cilju detaljnijeg ispitivanja uloge emocionalnih deficita kao mračnog jezgra, ispitivana je medijatorska uloga aleksitimije u odnosu mračnih crta i distresa. Kako postoje oprečna stanovišta o ulozi emocionalnih deficita u kontekstu mračnih crta, tj. da li oni doprinose boljem ili gorem mentalnom zdravlju, možemo pretpostaviti dva ishoda. Prema 
prvom stanovištu, po kojem emocionalni deficiti doprinose distresu u kontekstu mračnih crta, možemo pretpostaviti da će mračne crte koje su okarakterisane većim antagonizmom biti pozitivno povezane sa distresom zbog više aleksitimije. Prema drugom stanovištu, po kojem emocionalni deficiti doprinose umanjenju distresa u kontekstu mračnih, možemo očekivati da pretežno antagonističke mračne crte neće biti značajno povezane sa distresom zbog veće aleksitimije, tj. da će aleksitimija "ublažiti” negativnu vezu između mračnih crta i distresa. Kada su u pitanju agensni aspekti mračnih crta, u oba slučaja možemo očekivati da će oni biti negativno povezani s distresom zbog niže aleksitimije.

\section{Metod}

\section{Uzorak i procedura}

U istraživanju je učestvovalo 355 ispitanika (71.3\% ženskog pola), starosti od 18 do 57 godina $(A S=25.55, S D=7.54$ ). Prema obrazovnom statusu 26 (7.3\%) ispitanika ima završenu srednju četvorogodišnju školu, 195 (54.9\%) su studenti, 6 (1.7\%) ima završenu višu školu i 128 (36.1\%) ima završen fakultet, master ili doktorske studije. Upitnici su distribuirani preko Facebook-a, metodom snežne grudve. Pre pristupa upitnicima ispitanici su pročitali informacije o istraživanju (navedeno je da je cilj istraživanja ispitivanje određenih crta ličnosti koje mogu biti faktori rizika za emocionalne i socijalne probleme) i dali saglasnost za učešće. Ispitivanje je bilo anonimno i dobrovoljno. Na kraju upitnika je ispitanicima prikazana pisana forma debrifinga. Važno je naglasiti da su podaci prikupljeni pre proglašenja pandemije koronavirusa u Srbiji.

\section{Instrumenti}

Toronto skala aleksitimije (Twenty-Item Toronto Alexithymia Scale - TAS-20: Bagby et al., 1994, za adaptaciju na srpskom videti Trajanović i sar., 2013)

TAS-20 se sastoji od 20 ajtema kojima se meri tri dimenzije aleksitimije: poteškoće u identifikaciji sopstvenih osećanja (7 ajtema, npr. 
"Imam osećanja koja ne mogu tačno da prepoznam."), poteškoće u opisivanju sopstvenih osećanja (5 ajtema, npr. "Teško mi je da pronađem prave reči da opišem kako se osećam.) i eksterno orijentisano razmišljanje (8 ajtema, npr. "Radije prepuštam da se stvari odvijaju same od sebe nego što pokušavam da shvatim razlog zašto se to dešava.") koje se odnosi i na praktičan način razmišljanja i smanjenu sposobnost maštanja.

Skala depresije, anksioznosti i stresa (Depression Anxiety Stress Scale DASS-21; Lovibond \& Lovibond, 1995, za adaptaciju na srpskom videti zvaničan sajt, http://wwW2.psy.unsw.edu.au/Groups/Dass/Serbian/Serbian.htm)

DASS-21 sadrži 21 ajtem kojima se mere tri domena psihološkog distresa, svaki sa po 7 ajtema - depresija (npr. "Nisam imao/la nikakvo lepo osećanje.), anksioznost (npr. "Imao/la sam poteškoća sa disanjem (recimo, osetio/la sam ubrzano disanje a nisam se fizički zamorio/la." i "Osećao/la sam se uplašeno bez razloga.") i stres (npr. "Teško mi je da se opustim."). S obzirom na to ove tri dimenzije visoko međusobno koreliraju (od .66 do .75), u analizama će biti korišćen samo ukupni skor kao opšta mera distresa.

Levensonova skala psihopatije (Levenson Self-Report Psychopathy Scales LSRP: Levenson et al., 1995, za adaptaciju na srpskom videti Dinić et al., 2020b)

LSRP sadrži 26 ajtema koji su grupisani u dve dimenzije: primarnu (16 ajtema) i sekundarnu psihopatiju (10 ajtema). Primarna psihopatija obuhvata ajteme koji se odnose na interpersonalne i afektivne karakteristike psihopatije (npr. "Glavna svrha u životu mi je da dobijem koristi što više mogu."), dok impulsivnost i antisocijalno ponašanje predstavljaju karakteristike sekundarne psihopatije (npr. "Nalazim se iznova u istim nevoljama."). 
Petofaktorski inventar makijavelizma (Five Factor Machiavellianism Inventory - FFMl: Collison et al., 2018)

FFMI se sastoji od 52 ajtema kojima se mere tri faktora višeg reda od kojih svaki obuhvata nekoliko faceta: 1) makijavelistički antagonizam (20 ajtema, npr. "Ponekad moraš da slažeš da bi stvari bile urađene.") koji uključuje sebičnost, neskromnost, manipulativnost, beskrupuloznost i ciničnost, 2) makijavelistička delotvornost (24 ajtema, npr. "Imam jaku potrebu za mocí.) koja obuhvata uspeh, aktivnost, asertivnost, kompetentnost, samopouzdanje i nepovredljivost, i 3) makijavelističko planiranje (8 ajtema, npr. "Pažljivo razmotrim posledice pre nego što donesem odluku.") koje obuhvata promišljenost i red. S obzirom na to da inventar nije još primenjivan na srpskom jeziku, u skladu sa originalnim istraživanjem, faktorska struktura je ispitivana na 13 faceta, a primenjena je analiza glavnih komponenti kako bi se zadržao što veći procenat objašnjene varijanse. Na osnovu paralelne analize je moguće izolovati 3 komponente nad kojima je primenjena promax rotacija. Struktura komponenti većinom odražava originalnu strukturu (Tabela 1). Izuzetak je faceta beskrupuloznosti koja ostvaruje značajno, ali marginalno opterećenje samo na faktoru delotvornosti, umesto na faktoru antagonizma, i faceta uspeh koja ostvaruje marginalna opterećenja na faktorima antagonizma i reda, a ne na delotvornosti. Korelacije između faktora su niske (-.19, .18 i .06), tako da se može zaključiti da je reč o nezavisnim faktorima. Generalno, može se zaključiti da je moguće ekstrahovati tri faktora čiji dominantni sadržaj odgovara originalnoj strukturi. Kako bi rezultati bili uporedivi sa drugim istraživanjima, u radu je zadržan originalni način skorovanja faktora makijavelizma. 


\section{Tabela 1}

Matrica sklopa komponenti Petofaktorskog inventara makijavelizma

\begin{tabular}{lccc}
\hline Facete makijavelizma & $\begin{array}{c}\text { Makijavelistička } \\
\text { delotvornost }\end{array}$ & $\begin{array}{c}\text { Makijavelistički } \\
\text { antagonizam }\end{array}$ & $\begin{array}{c}\text { Makijavelističko } \\
\text { planiranje }\end{array}$ \\
\hline $\begin{array}{l}\text { Uspeh } \\
\text { Aktivnost }\end{array}$ & .76 & .37 & -.39 \\
Sebičnost & .74 & .78 & \\
Asertivnost & .86 & & .80 \\
Kompetentnost & .55 & .46 & .34 \\
Promišljenost & .39 & & .52 \\
Nepovredljivost & .39 & & \\
Beskrupuloznost & .85 & & \\
Red & & .65 & \\
Samopouzdanje & & .69 & \\
Manipulativnost & 25.9 & 17.9 & \\
Bezosećajnost & & & \\
Cinizam & & & \\
\hline \% ukupne varijanse & & & \\
\hline
\end{tabular}

Napomena: Prikazana su opterećenja $\geq .32$

Kratka verzija Petofaktorskog inventara narcizma (Short Form of the FiveFactor Narcissism Inventory - FFNI-SF: Sherman et al., 2015, za adaptaciju na srpskom videti Dinić et al., 2021a)

FFNI sadrži 60 ajtema kojima se mere tri ili dva faktora višeg reda. Kako smo hteli da izdvojimo antagonistički aspekt narcizma, primenili smo skorovanje s tri faktora višeg reda: 1) narcistički antagonizam (32 ajtema, npr. "Verujem da imam pravo na posebne privilegije.") koji obuhvata facete manipulacije, eksploatacije, umišljenih prava (osećaja povlašćenosti), nedostatka empatije, arogancije, reaktivnog besa, nepoverenja i traženje uzbuđenja, 2) narcistička ekstraverzija koja se odnosi na grandiozni aspekt narcizma bez antagonizma (16 ajtema, npr. "Verujem da će jednog dana većina ljudi znati za moje ime.") koja obuhvata facete traženja priznanja, autoritativnosti, grandioznih fantazija i egzibicionizma, i 3) narcistički neuroticizam koji se odnosi na vulnerabilni aspekt narcizma bez 
antagonizma (12 ajtema, npr. "Često osećam kao da su mi potrebni komplimenti od drugih da bih bio siguran u sebe.") koji obuhvata facete stida, niske ravnodušnosti i potrebe za divljenjem.

Procena sadističke ličnosti (Assessment of Sadistic Personality - ASP: Plouffe et al., 2017, za adaptaciju na srpskom videti Dinić et al., 2020c)

ASP se sastoji od 9 ajtema koji mere supklinički sadizam, tj. njegove indikatore poput pokoravanja, traženja zadovoljstva u tuđoj patnji i bezosećajnosti (primer ajtema „Biti zao prema drugima može biti zabavno.").

Uz sve ajteme, osim za ajteme DASS-21, priložena je petostepena skala Likertovog tipa za odgovaranje (od $1=$ potpuno se ne slažem do $5=$ potpuno se slažem). U slučaju DASS-21, skala za odgovaranje je četvorostepena (od $0=$ ni malo do $3=$ uglavnom ili skoro uvek), a period procene se odnosi na poslednjih nedelju dana. Deskriptivni podaci i Kronbahove alfe svih varijabli su prikazani u Tabeli 2.

Plan obrade podataka

Najpre je proverena distribucija skorova na korišćenim skalama uvidom u vrednosti skjunisa i kurtozisa. Jedino odstupanje od vrednosti preporučenih za normalu distribuciju (+/-2, videti više u Dinić, 2019) je bilo primetno kod sadizma $(S K=2.01, K u=5.06)$. Međutim u preliminarnim analizama je utvrđeno da se isti rezultati dobijaju i kada se koristi sirovi i normalizovani skor, tako da su prikazani rezultati na sirovim skorovima. U cilju provere da li se mogu detektovati antagonističke i relativno adaptivneagensne karakteristike mračnih crta, sprovedena je faktorska analiza (metod maksimalne verodostojnosti, u softveru JASP v. 0.13.1., JASP Team, 2020) nad skalama mračnih crta. Broj faktora je određen preko paralelne analize u istom softveru, a s obzirom na očekivanje da faktori međusobno koreliraju jer potiču iz istog domena mračnih crta, primenjena je kosa promax rotacija. Kao značajna opterećenja su razmatrana opterećenja $\geq .32$ (Tabachnick \& Fidell, 2019), a ekstrahovani faktori korišćeni u daljim analizama. U cilju ispitivanja relacija faktora aleksitimije i mračnih crta, najpre je primenjena set korelaciona analiza (analiza je rađena u R paketu "psych", Revelle, 2020). Ova 
analiza je sprovedena s ciljem dobijanja procenta zajedničke varijanse između dva skupa varijabli. Potom su izračunati Pirsonovi koeficijenti korelacije. Zarad dobijanja uvida u predikciju faktora aleksitimije i opšteg distresa na osnovu mračnih crta primenjene su hijerarhijske regresione analize u softveru IBM SPSS v.23 for Windows (IBM Corp., 2015). U njima su u prvom koraku prediktora uvedeni pol i starost zarad kontrole njihovih efekata, a u drugom facete Mračne tetrade, dok su faktori aleksitimije i opšti distres bili kriterijumi, ponaosob. Ova analiza je ponovljena i sa faktorima mračnih crta kao prediktorima. Na kraju, u cilju ispitivanja medijacionih efekata faktora aleksitimije na odnos između mračnih crta i distresa, sprovedena je analiza paralelne medijacije u kojoj je kriterijum bio opšti distres, paralelni medijatori - tri faktora aleksitimije, a prediktori, ponaosob, skale mračnih crta, uz kontrolu pola i starosti (analiza je sprovedena u makrou PROCESS v3.5. za SPSS, Hayes, 2017). Ova analiza je ponovljena sa faktorima mračnih crta kao prediktorima. Izračunati su 95\%-tni intervali poverenja primenom metode samouzorkovanja na 5000 podešenih uzoraka.

\section{Rezultati}

\section{Deskriptivni podaci}

Pouzdanost izražena preko interne konzistencije je zadovoljavajuća, izuzev za skorove na makijavelističkom planiranju i eksterno orijentisanom mišljenju (Tabela 2), što treba uzeti u obzir prilikom interpretacije rezultata. Prosečni skor na TAS-20 iznosi $48.37(S D=14.38)$, što bi se okarakterisalo kao niski skor (odsustvo aleksitimije) prema normama koje su ponudili autori ( 51, videti Bagby et al., 1994). Prema ovim normama, na celom uzorku ima 70 (19.7\%) ispitanika čiji bi se skorovi (od 52 do 60) interpretirali kao mogućnost aleksitimije i 82 (23.1\%) čiji bi se skorovi interpretirali kao prisustvo aleksitimije ( $\geq 61$ ), dok bi se kod oko polovine ispitanika (203, odnosno $57.2 \%)$ skorovi interpretirali kao odsustvo aleksitimije. Ukupan skor na skali DASS-21 je viši u odnosu na skor ostvaren na uzorku studenata iz Srbije ( $A S=$ 13.21, $S D=11.01$, videti Jovanović i sar., 2014). Norme za ovu skalu postoje za supskale (Lovibond \& Lovibond, 1995), te uvidom u njihove skorove smo 
zaključili da visoki skorovi potiču od indikatora stresa i anksioznosti koji se mogu okarakterisati kao umereno povišeni, dok je bi se skor na depresiji okarakterisao kao blago povišen. Za ostale skale ne postoje norme, ali može se zaključiti da su skorovi u rangu sa skorovima dobijenim u ranijim istraživanjima na srpskim uzorcima (Dinić et al., 2020b, 2020c).

\section{Tabela 2}

Deskriptivni podaci i Konbahova alfa

\begin{tabular}{lccc}
\hline Varijable & $A S$ & $S D$ & $\alpha$ \\
\hline Poteškoće u identifikaciji sopstvenih osećanja & 17.94 & 7.08 & .87 \\
Poteškoće u opisivanju sopstvenih osećanja & 13.67 & 5.29 & .82 \\
Eksterno orijentisano mišljenje & 16.77 & 5.11 & .65 \\
\hline Opšti distres & 20.95 & 15.51 & .95 \\
\hline Primarna psihopatija & 33.72 & 7.95 & .72 \\
Sekundarna psihopatija & 23.99 & 7.00 & .75 \\
\hline Makijavelistički antagonizam & 51.79 & 9.74 & .77 \\
Makijavelistička delotvornost & 80.20 & 13.99 & .86 \\
Makijavelističko planiranje & 27.54 & 4.10 & .55 \\
\hline Narcistički antagonizam & 72.25 & 18.54 & .90 \\
Narcistička ekstraverzija & 49.50 & 12.44 & .88 \\
Narcistički neuroticizam & 36.66 & 10.18 & .87 \\
\hline Sadizam & 15.03 & 4.68 & .90 \\
\hline
\end{tabular}

\section{Zajednička faktorska analiza faceta Mračne tetrade}

Na osnovu paralelne analize zadržana su dva faktora nad kojima je primenjena kosa promax rotacija. Korelacija između faktora je niska (-.06), te je zapravo reč o nezavisnim dimenzijama i odabir ortogonalne rotacije ne menja rezultat. Na prvom faktoru (31\% zajedničke varijanse) najviša opterećenja imaju antagonistički aspekti makijavelizma i narcizma i primarna psihopatija, te sadizam i narcistička ekstraverzija, pa je ovaj faktor nazvan Antagonizam (Tabela 3). Ovaj faktor okuplja ono što su centralni elementi Mračne tetrade i sržni sadržaji mračnih crta. Na drugom faktoru (21\% zajedničke varijanse) upadljivo najveći doprinos ima makijavelistička 
delotvornost, a potom sekundarna psihopatija i narcistički neuroticizam, oba u negativnom smeru, i narcistička ekstraverzija u pozitivnom smeru, te je ovaj faktor nazvan Delotvornost. Ovaj faktor obuhvata periferne karakteristike Mračne tetrade i crte koje su parcijalizovane u odnosu na antagonističke karakteristike. Primetno je da makijavelističko planiranje ne ostvaruje značajno opterećenje ni na jednom faktoru, dok narcistička ekstraverzija i sekundarna psihopatija ostvaruju značajna opterećenja na oba faktora. Ipak, opterećenje na primarnim faktorima u slučaju ove dve facete je upadljivo više u odnosu na njihova sekundarna opterećenja.

\section{Tabela 3}

Opterećenja na faktorima faceta Mračne tetrade

\begin{tabular}{lcc}
\hline Mračne crte & Antagonizam & Delotvornost \\
\hline Primarna psihopatija & .76 & \\
Sekundarna psihopatija & .37 & -.59 \\
Makijavelistički antagonizam & .75 & .98 \\
Makijavelistička delotvornost & & \\
Makijavelističko planiranje & & \\
Narcistički antagonizam & .91 & .44 \\
Narcistička ekstraverzija & .60 & -.59 \\
Narcistički neuroticizam & & \\
Sadizam & .52 & \\
\hline
\end{tabular}

Napomena: Prikazana su opterećenja $\geq .32$

Korelacije između faktora aleksitimije i crta Mračne tetrade

Rezultati set korelacione analize pokazuju da faktori aleksitimije i facete mračnih crta dele 56\% zajedničke varijanse, dok faktori aleksitimije i faktori mračnih crta dele $41 \%$ zajedničke varijanse. Najviše korelacije s faktorima aleksitimije, i to posebno sa teškoćama u identifikovanju i opisivanju sopstvenih emocija, kao i sa opštim distresom, ostvaruju sekundarna psihopatija u pozitivnom smeru i makijavelistička delotvornost u negativnom smeru, a potom i narcistički neuroticizam, u pozitivnom smeru (Tabela 4). Narcistička ekstraverzija ne ostvaruje značajne korelacije ni sa jednim faktorom aleksitimije, 
ni sa distresom, dok narcistički i makijavelistički antagonizam, primarna psihopatija i sadizam ostvaruju niske pozitivne korelacije sa svim faktorima aleksitimije i distresom. S druge strane, makijavelističko planiranje ostvaruje niske negativne korelacije sa ovim varijablama. Korelacije sa eksterno orijentisanim mišljenjem su relativno niske, a među njima nešto više korelacije ostvaruju makijavelistički antagonizam i primarna psihopatija u pozitivnom smeru, kao i makijavelističko planiranje, u negativnom smeru.

Kada su u pitanju korelacije sa faktorima Mračne tetrade, antagonizam ostvaruje pozitivne i niske korelacije sa opštim distresom i faktorima aleksitimije, a delotvornost negativne i umerene korelacije sa opštim distresom i faktorima aleksitimije, izuzev sa eksternim mišljenjem s kojim ostvaruje nisku negativnu korelaciju (Tabela 4).

\section{Tabela 4}

Korelacije između aleksitimije, opšteg distresa i crta Mračne tetrade

\begin{tabular}{|c|c|c|c|c|c|}
\hline & & $\begin{array}{c}\text { Poteškoće u } \\
\text { identifikaciji } \\
\text { sopstvenih } \\
\text { osećanja }\end{array}$ & $\begin{array}{l}\text { Poteškoće u } \\
\text { opisivanju } \\
\text { sopstvenih } \\
\text { osećanja }\end{array}$ & $\begin{array}{c}\text { Eksterno } \\
\text { orijentisano } \\
\text { mišljenja }\end{array}$ & $\begin{array}{c}\text { Opšti } \\
\text { distres }\end{array}$ \\
\hline & Opšti distres & $.66^{\star \star \star}$ & $.49^{* * *}$ & $.18^{* * *}$ & 1 \\
\hline \multirow{9}{*}{ Facete } & Primarna psihopatija & $.17^{\star \star}$ & $.17^{\star \star \star}$ & $.31^{* \star *}$ & $.17^{\star *}$ \\
\hline & Sekundarna psihopatija & $.61^{\star \star \star}$ & $.52^{\star \star \star}$ & $.35^{\star \star \star}$ & $.61^{\star \star \star}$ \\
\hline & Makijavelistički antagonizam & $.13^{\star *}$ & $.14^{* *}$ & $.22^{\star \star \star}$ & $.12^{*}$ \\
\hline & Makijavelistička delotvornost & $-.46^{\star * *}$ & $-.46^{* * *}$ & $-.24^{\star * *}$ & $-.52^{\star \star *}$ \\
\hline & Makijavelističko planiranje & $-.18^{\star \star \star}$ & $-.14^{\star *}$ & $-.22^{* * *}$ & $-.13^{* *}$ \\
\hline & Narcistički antagonizam & $.28^{\star * *}$ & $.21^{* * *}$ & $.25^{\star \star \star}$ & $.32^{\star * *}$ \\
\hline & Narcistička ekstraverzija & .05 & -.03 & -.07 & .04 \\
\hline & Narcistički neuroticizam & $.40^{\star \star \star \star}$ & $.33^{\star \star \star}$ & .03 & $.45^{\star \star \star}$ \\
\hline & Sadizam & $.14^{\star \star}$ & $.13^{\star \star}$ & $.19^{\star \star \star}$ & $.14^{* *}$ \\
\hline \multirow[t]{2}{*}{ Faktori } & Antagonizam & $.24^{\star \star \star}$ & $.18^{\star * \star}$ & $.25^{\star \star \star}$ & $.25^{\star \star \star}$ \\
\hline & Delotvornost & $-.50^{\star \star \star}$ & $-.50^{\star \star \star}$ & $-.29 * \star \star$ & $-.57^{\star \star \star}$ \\
\hline
\end{tabular}

Napomena: ${ }^{\star \star \star} p<.001,{ }^{* \star} p<.01,{ }^{*} p<.05$ 
Korelacija između poteškoća u identifikaciji i u opisivanju sopstvenih emocija je visoka (.75), a umerena između poteškoća u identifikaciji sopstvenih emocija i eksterno orijentisanog mišljenja (.41), kao i poteškoća u opisivanju sopstvenih emocija i eksterno orijentisanog mišljenja (.33). Korelacije između faceta mračnih crta se kreću od -.58 (između makijavelističke delotvornosti i narcističkog neuroticizma) do .68 (između narcističkog i makijavelističkog antagonizma i između primarne psihopatije i narcističkog antagonizma). Puna tabela s korelacijama između faceta crta Mračne tetrade je prikazana u Prilogu A.

\section{Predikcija aleksitimije i opšteg distresa na osnovu crta Mračne tetrade}

Rezultati hijerarhijske regresione analize pokazuju da facete Mračne tetrade ostvaruju značajan inkrementalni doprinos u predikciji svih kriterijuma, povrh varijanse koje objašnjavaju pol i starost (Tabela 5). Najveći doprinos predikciji je ostvaren u slučaju predikcije distresa (50\%), pri čemu upadljivo više značajne doprinose ostvaruju makijavelistička delotvornost u negativnom smeru i narcistički antagonizam i sekundarna psihopatija u pozitivnom smeru. Pored njih, značajan pozitivan doprinos ostvaruje narcistička ekstraverzija, dok makijavelistički antagonizam ostvaruje negativan doprinos, odnosno suprotan smer predikcije u odnosu na korelacije, što je verovatno posledica deljene varijanse među mračnim crtama?. Naime, kada se narcistički antagonizam koji ostvaruje najvišu korelaciju s makijavelističkim antagonizmom (.68) ukloni, doprinos makijavelističkog antagonizma nije značajan ( $\beta=-.05, p=398$ ). Takođe je primetno i da narcistički neuroticizam ne ostvaruje značajni doprinos, uprkos visokim korelacijama, što je, takođe, posledica parcijalizovanja deljene varijanse među mračnim crtama.

\footnotetext{
${ }^{1}$ Vrednosti VIF se kreću od 1.12 do 3.51 i tolerancije od .41 do .90 , što se smatra prihvatljivim vrednostima i ne upućuje na problem s multikolinearnošću, ali vrednost uslovnog indeksa se kreće do 66.82, što upućuje na problem s multikolinearnošću (Kim, 2019).
} 
$\mathrm{U}$ predikciji faktora aleksitimije inkrementalni doprinos faceta Mračne tetrade se kreće od 21\% (eksterno orijentisano mišljenje) do $42 \%$ (poteškoća u identifikovanju sopstvenih osećanja, videti Tabelu 3). Sekundarna psihopatija u pozitivnom smeru i makijavelistička delotvornost u negativnom smeru su dosledni značajni prediktori svih faktora aleksitimije. Dodatno, poteškoće u identifikovanju sopstvenih osećanja predviđaju narcistički antagonizam i ekstraverzija, a eksterno mišljenje predviđa i primarna psihopatija.

\section{Tabela 5}

Predikcija faktora aleksitimije i opšteg distresa na osnovu faceta Mračne tetrade (uz kontrolu pola i starosti)

\begin{tabular}{|c|c|c|c|c|c|}
\hline & & $\begin{array}{c}\text { Poteškoće u } \\
\text { identifikovanju } \\
\text { sopstvenih } \\
\text { osećanja }\end{array}$ & $\begin{array}{l}\text { Poteškoće } \\
\text { u opisivanju } \\
\text { sopstvenih } \\
\text { osećanja }\end{array}$ & $\begin{array}{l}\text { Eksterno } \\
\text { orijentisano } \\
\text { mišljenja }\end{array}$ & $\begin{array}{l}\text { Opšti } \\
\text { distres }\end{array}$ \\
\hline Pol & & $-.10^{\star \star}$ & .03 & $.23^{\star \star \star}$ & -.07 \\
\hline Starost & & $-.10^{*}$ & $-.17^{\star \star \star}$ & -.02 & -.02 \\
\hline$R^{2}$ & & $.06^{* \star \star}$ & $.05^{\star \star \star}$ & $.06^{* * *}$ & $.03^{* *}$ \\
\hline \multirow{2}{*}{ Psihopatija } & $\begin{array}{l}\text { Primarna } \\
\text { psihopatija }\end{array}$ & -.05 & .02 & $.20^{\star *}$ & -.05 \\
\hline & $\begin{array}{l}\text { Sekundarna } \\
\text { psihopatija }\end{array}$ & $.39^{\star \star \star}$ & $.28^{* \star *}$ & $.16^{\star}$ & $.33^{\star \star *}$ \\
\hline \multirow{3}{*}{ Makijavelizam } & Antagonizam & -.06 & .01 & -.02 & $-.15^{\star \star}$ \\
\hline & Delotvornost & $-.30^{\star \star \star}$ & $-.35^{\star \star \star}$ & $-.21^{*}$ & $-.44^{\star * *}$ \\
\hline & Planiranje & .01 & .01 & -.08 & .08 \\
\hline \multirow[t]{3}{*}{ Narcizam } & Antagonizam & $.15^{\star}$ & .06 & .11 & $.31^{\star \star \star}$ \\
\hline & Ekstraverzija & $.13^{*}$ & .06 & -.11 & $.16^{\star *}$ \\
\hline & Neuroticizam & .06 & .04 & -.09 & .05 \\
\hline Sadizam & & .04 & .02 & .02 & .01 \\
\hline$\Delta R^{2}$ & & $.42^{\star \star \star}$ & $.32^{\star \star \star}$ & $.21^{\star \star \star}$ & $.50^{\star \star \star}$ \\
\hline Total $R^{2}$ & & $.47^{\star \star \star}$ & $.37^{\star \star \star}$ & $.27^{\star \star \star}$ & $.53^{\star \star \star}$ \\
\hline
\end{tabular}

Napomene: Kodovi za pol su $0=$ ženski, $1=$ muški. ${ }^{\star \star \star} p<.001,{ }^{\star \star} p<.01,{ }^{*} p<.05$ 
Analiza je ponovljena sa faktorima Mračne tetrade kao prediktorima². Faktori mračnih crta ostvaruju značajan inkrementalni doprinos u predikciji distresa (41\%), kao i faktora aleksitimije (33\%, 29\% i 16\%, redom za tri faktora). U svim slučajevima doprinosi faktora delotvornosti su visoki i negativni, dok su doprinosi faktora antagonizma niski i pozitivni (Tabela 6).

\section{Tabela 6}

Predikcija faktora aleksitimije i opšteg distresa na osnovu faktora Mračne tetrade (uz kontrolu pola i starosti)

\begin{tabular}{|c|c|c|c|c|}
\hline & $\begin{array}{c}\text { Poteškoće u } \\
\text { identifikovanju } \\
\text { sopstvenih osećanja }\end{array}$ & $\begin{array}{l}\text { Poteškoće u } \\
\text { opisivanju } \\
\text { sopstvenih } \\
\text { osećanja }\end{array}$ & $\begin{array}{l}\text { Eksterno } \\
\text { orijentisano } \\
\text { mišljenja }\end{array}$ & $\begin{array}{c}\text { Opšti } \\
\text { distres }\end{array}$ \\
\hline Pol & $-.14^{\star \star \star}$ & $\begin{array}{l}-.01 \\
\end{array}$ & $.25^{\star \star \star}$ & $-.12^{\star \star}$ \\
\hline Starost & $-.13 * \star$ & $-.19^{\star \star \star}$ & .00 & -.06 \\
\hline$R^{2}$ & $.06^{\star \star *}$ & $.05^{\star \star \star}$ & $.06^{* * *}$ & $.03^{* *}$ \\
\hline Antagonizam & $.30^{\star \star \star}$ & $.21^{\star \star \star}$ & $.26^{\star \star \star}$ & $.33^{\star \star \star}$ \\
\hline Delotvornost & $-.52^{\star \star \star}$ & $-.52^{\star \star \star}$ & $-.34^{\star \star *}$ & $-.59^{\star \star \star}$ \\
\hline$\Delta R^{2}$ & $.33^{\star \star \star}$ & $.29^{\star \star \star}$ & $.16^{\star \star \star}$ & $.41^{\star \star \star}$ \\
\hline Total $R^{2}$ & $.38^{\star \star \star}$ & $.34^{\star \star \star}$ & $.22^{\star \star \star}$ & $.45^{\star \star \star}$ \\
\hline
\end{tabular}

Napomene: Kodovi za pol su $0=$ ženski, $1=$ muški. ${ }^{* \star} p<.001,{ }^{* \star} p<.01,{ }^{*} p<.05$

Medijacioni efekti faktora aleksitimije u predikciji distresa na osnovu crta Mračne tetrade

Pun medijacioni model sa kovarijetetima i facetama Mračne tetrade kao pojedinačnim prediktorima objašnjava od 43\% (makijavelistički antagonizam i narcistička ekstraverzija) do 51\% (sekundarna psihopatija) varijanse opšteg distresa. U slučaju kada su prediktori faktori Mračne tetrade, objašnjeno je 45\% (antagonizam) i 52\% (delotvornost) opšteg distresa.

\footnotetext{
2 Vrednosti VIF se kreću od 1.01 do 1.04, tolerancije od .96 do .995 i vrednosti uslovnog indeksa se kreću do 9.24, što upućuje na zaključak da nema problema s multikolinearnošću (Kim, 2019).
} 
Analiza paralelne medijacije je pokazala da od svih faktora aleksitimije, jedino faktor poteškoća u identifikaciji osećanja ostvaruje značajan medijacioni efekat u predikciji opšteg distresa na osnovu svih faceta i faktora mračnih crta, osim narcističke ekstraverzije (Tabela 7). Dobijeni značajni medijacioni efekat upućuje na to da primarna i sekundarna psihopatija, makijavelistički antagonizam, narcistički antagonizam i neuroticizam, sadizam i faktor antagonizma ostvaruju pozitivnu vezu sa opštim distresom zbog većih problema u identifikaciji osećanja. S druge strane, makijavelistička delotvornost i planiranje, pa samim tim i faktor delotvornosti, ostvaruju negativnu vezu sa opštim distresom zbog manjih problema u identifikaciji osećanja. Valja napomenuti da se kauzalni smer veza ne može pretpostaviti s obzirom na to da je nacrt kros-sekcionalni.

\section{Tabela 7}

Direktni efekti crta Mračne tetrade i indirektni preko poteškoća u identifikaciji osećanja u predikciji opšteg distresa

\begin{tabular}{lcc}
\hline Prediktor (faceta) & Direktan efekat & Indirektan efekat \\
\hline Primarna psihopatija & .08 & $.11(.04 ; .19)$ \\
Sekundarna psihopatija & $.36^{\star \star \star}$ & $.29(.21 ; .37)$ \\
Makijavelistički antagonizam & .04 & $.10(.02 ; .18)$ \\
Makijavelistička delotvornost & $-.30^{\star \star \star}$ & $-.27(-.34 ;-.19)$ \\
Makijavelističko planiranje & -.02 & $-.13(-.21 ;-.06)$ \\
Narcistički antagonizam & $.17^{\star \star *}$ & $.17(.11 ; .25)$ \\
Narcistička ekstraverzija & .003 & nema \\
Narcistički neuroticizam & $.23^{\star \star \star}$ & $.23(.15 ; .31)$ \\
Sadizam & .07 & $.11(.03 ; .18)$ \\
\hline Prediktor (faktor) & $.12^{\star \star}$ & $.16(.09 ; .23)$ \\
Antagonizam & $-.35^{\star \star \star}$ & $-.28(-.36 ;-.21)$ \\
Delotvornost & Nete. Za direktne efekte je prikazana \\
\hline Napomene: Prikazane su standardizovane & betrack \\
značajnost, a za indirektne efekte su prikazani $95 \%$-ni intervali poverenja. U svim \\
analizama su kovarijeteti pol, starost i ostale mračne crte koje nisu uvedene kao \\
prediktor.
\end{tabular}




\section{Diskusija}

Osnovni cilj ovog istraživanja je usmeren na ispitivanje relacija crta Mračne tetrade sa aleksitimijom i distresom, uzevši u obzir multidimenzionalnost mračnih crta, te njihove maladaptivne i adaptivne aspekte. Rezultati pokazuju da mračne crte i faktori aleksitimije dele 56\% zajedničke varijanse. U odnosu na prethodna istraživanja u kojima je pokazano da npr. bezosećajnost kao faceta psihopatološke crte antagonizma deli $78 \%$ zajedničke varijanse sa mračnim crtama, a sama dimenzija antagonizma čak 96\% (Dinić et al., 2021b), čini se da aleksitimija nije dobar kandidat za ispitivanje mračnog jezgra. Naime, mračno jezgro obuhvata i nedostatak afektivne empatije, a ne samo kognitivne (npr. Dinić et al., 2020b, 2021b) s kojom je aleksitimija usko povezana.

Bez obzira na to što je procenat deljene varijanse manji u odnosu na druge kandidate mračnog jezgra, on nikako nije zanemarljiv i ukazuje na prisustvo problema u razumevanju sopstvenih emocija i sličnih emocionalnih deficita u okviru mračnih crta. Rezultati pokazuju da postoje složene veze između mračnih crta i aleksitimije, te da različite facete mračnih crta ostvaruju suprotan obrazac veza sa faktorima aleksitimije. Dominantni korelati i prediktori sva tri faktora aleksitimije su sekundarna psihopatija, u pozitivnom smeru, i makijavelistička delotvornost, u negativnom smeru. Upravo kombinacija visoke makijavelističke delotvornosti i niske sekundarne psihopatije izdvaja se u okviru zajedničkog faktora mračnih crta delotvornosti, koji je očekivano negativno povezan s faktorima aleksitimije i distresom.

Rezultati potvrđuju ulogu sekundarne psihopatije u emocionalnim deficitima koja je dobijena u prethodnim istraživanjima (npr. Burghart \& Mier, 2021). Može se pretpostaviti da su nedostatak bihejvioralne kontrole, učestala promena raspoloženja i neadekvatna emocionalna regulacija, koje su karakteristične za sekundarnu psihopatiju, povezane s nemogućnošću uvida u sopstvene emocije. Pored toga, na osnovu rezultata istraživanja može se zaključiti da je sekundarna psihopatija najdisfunkcionalnija mračna crta kada su u pitanju relacije s mentalnim zdravljem. U prethodnim 
istraživanjima je dobijeno da sekundarna psihopatija ostvaruje najviše korelacije s različitim aspektima psihološkog distresa, odnosno sa lošim blagostanjem, većim prisustvom zdravstvenih i psiholoških simptoma, te problemima u socijalnom i generalnom funkcionisanju (Dinić et al., 2020a). Upravo nerazumevanje emocija osobe s višom sekundarnom psihopatijom dovodi do više anksioznosti, depresivnosti i stresa, budući da nemaju kapacitete za prevladavanje emocija i za adekvatnu emocionalnu regulaciju.

Među ključnim korelatima aleksitimije i distresa izdvaja se i makijavelistička delotvornost, u negativnom smeru. Ovaj aspekt makijavelizma se odnosi na dominaciju, ambicioznost, samopouzdanje, procenu visoke kompetencije i emocionalne stabilnosti i povezuje se s višom prijatnošću, ekstraverzijom i savesnošću, a nižim neuroticizmom (Collison et al., 2018). Na osnovu profila koji obuhvata među bazičnim crtama može se pretpostaviti adaptivni karakter makijavelističke delotvornosti. Međutim, makijavelizam je averzivna crta čije su ključne karakteristike antagonizam, bezosećajnost, cinizam itd., pa se postavlja pitanje da li je ovako definisana delotvornost zaista aspekt makijavelizma koji se odnosi na strateško planiranje u cilju obezbeđivanja koristi na račun drugih, ili se može smarati orijentacijom na postignuće uz kompetitivnost koja može biti i "zdrava”. Naime, u validaciji FFMI inventara (Kückelhaus et al., 2021) pokazano je da ova dimenzija makijavelizma nije značajno povezana sa Poštenjemskromnošću koje se smatra jednim od sržnih korelata mračnih crta među bazičnim osobinama ličnosti (npr. Book et al., 2016).

Pored ovih dominantnih prediktora aleksitimije, među značajnim korelatima i prediktorima poteškoća prilikom opisivanja osećanja i distresa izdvaja se i narcistički antagonizam. Uloga narcističkog antagonizma u emocionalnim deficitima je očekivana, budući da sama dimenzija obuhvata indikatore emocionalnih deficita (npr. nedostatak empatije). Takođe, facete narcističkog antagonizma su u prethodnom istraživanju ostvarile pozitivne veze sa depresijom i anksioznošću (Miller et al., 2013). Međutim, na ovom mestu treba detaljnije objasniti efekat narcističke ekstraverzije i neuroticizma. Naime, dok narcistički neuroticizam ostvaruje značajne pozitivne korelacije sa faktorima aleksitimije i distresom, što je u skladu sa 
prethodnim istraživanjima (Miller et al., 2013), u regresionoj analizi ova dimenzija ne ostvaruje značajnu predikciju. S druge strane, narcistička ekstraverzija ne ostvaruje značajne korelacije, ali ostvaruje značajni prediktivni doprinos, što je očigledno posledica parcijalizovanja deljene varijanse među mračnim crtama u regresionom modelu. $U$ prethodnim istraživanjima neke facete narcističke ekstraverzije su ostvarile negativnu korelaciju sa depresijom i anksioznošću, a neke neznačajnu (Miller et al., 2013), te bi se mogla pretpostaviti negativna ili neznačajna veza narcističke ekstraverzije sa distresom, što je i dobijeno u našem istraživanju (korelacija nije bila značajna sa distresom). Zanimljivo je da je narcistička ekstraverzija obuhvaćena i u okviru antagonističkog faktora i faktora delotvornosti crta Mračne tetrade, iako bi njen sadržaj trebao biti parcijalizovan od antagonističkog jezgra (Glover et al., 2012). Prethodna istraživanja takođe ukazuju na to da narcistička ekstraverzija, kao i narcistički antagonizam, ostvaruju relativno ujednačene i više korelacije sa crtama Mračne trijade u odnosu na narcistički neuroticizam koji ostvaruje niske negativne ili neznačajne korelacije (Papageorgiou et al., 2021). lako neki autori razlikuju adaptivne i maladaptivne aspekte narcizma, prethodna istraživanja ukazuju na to da se i oni aspekti narcizma koji se smatraju adaptivnim, kao što je npr. liderstvo, pozitivno povezuju s kontrolom ponašanja i ekstraverzijom, ali i sa mračnim crtama i moralnim deficitima (Ackerman et al., 2011; Dinić \& Vujić, 2019). Ovakvi rezultati upućuju na njihov maladaptivni karakter ali koji je više prikriven i ne tako eksplicitan kao u slučaju narcističkog antagonizma. Dodatno, neki autori su ponudili drugačiji način skorovanja FFNI u okviru kojeg se eliminišu facete grandioznih fantazija, traženja uzbuđenja i arogancije jer ne doprinose diferencijaciji faktora narcizma, a manipulativnost je prelocirana u okviru faktora narcističke ekstraverzije (Rogoza et al., 2020). Buduća istraživanja bi trebalo detaljnije da ispitaju validnost narcističke ekstraverzije i njenu ulogu u predikciji maladaptivnih ishoda.

Mračne crte generalno ostvaruju niske korelacije s eksterno orijentisanim mišljenjem. Ovaj rezultati nije iznenađujući, budući da je ovaj faktor aleksitimije nisko povezan sa preostala dva faktora, a distinktivna 
karakteristika mu je što ne uključuje direktno iskustvo emocija (Bagby et al., 1994). Ipak, značajni doprinos predikciji eksternog mišljenja ostvaruje i primarna psihopatija, pored sekundarne psihopatije i makijavelističke delotvornosti. Povezanost primarne psihopatije sa eksternim mišljenjem je u skladu s prethodnim istraživanjima (npr. Lander et al., 2012). Može se pretpostaviti da se osobe s izraženom primarnom psihopatijom ne bave svojim unutrašnjim svetom i generalno ih karakteriše nedostatak imaginacije i pragmatičnost, te su više orijentisane na signale potencijalne pretnje iz svog okruženja, kako bi preduhitrili sprečavanje sprovođenja njihovih ciljeva. U ranijem istraživanju pokazano je da se među osobama s primarnom psihopatijom može izdvoji grupa tzv. mračnih empata, koje karakteriše visoka kognitivna empatija, odnosno bolja detekcija i razumevanje emocija koji se koriste u svrhe manipulacije i eksploatacije drugih (Heym et al., 2019). Međutim, rezultati našeg istraživanja upućuju na pozitivne korelacije primarne psihopatije sa svim faktorima aleksitimije. Moguće je da je uspešnost prepoznavanja emocija kod primarne psihopatije ograničena samo na neke emocije (npr. strah, videti Del Gaizo \& Falkenbach, 2008) ili na prepoznavanje emocija kod drugih ali ne i kod sebe. Bez obzira na detekciju tzv. mračnih empata (Heym et al., 2019), kada se psihopatija posmatra dimenzionalno, ona češće ostvaruje pozitivne veze sa emocionalnim deficitima, a ono što je evidentno je da je sekundarna psihopatija važniji korelat aleksitimije u odnosu na primarnu (npr. Burghart \& Mier, 2021).

Mračne crte najviše objašnjen faktor poteškoća u identifikaciji sopstvenih osećanja i ovaj faktor aleksitimije jedini ostvaruje značajne medijacione efekte u odnosu između mračnih crta i opšteg distresa. Ovaj faktor uključuje i poteškoće u razlikovanju osećanja i telesnih senzacija usled uzbuđenja i generalno je povezana sa regijama u mozgu za emocionalnu samosvesnost (Goerlich, 2018). Možemo pretpostaviti da konfuzija koja se stvara usled nemogućnosti prepoznavanja i razumevanja emocionalnih stanja stvara frustraciju koja se povezuje sa lošim mentalnim zdravljem i većom učestalošću internalizovanih problema. Dobijeni rezultati imaju implikacije za osmišljavanje tretmana kojima bi se povećala svesnost i uviđanje afektivnih stanja kako kod sebe, tako i kod drugih, a čime bi se 
doprinelo boljem mentalnom zdravlju i regulaciji emocija, kao i smanjenju antisocijalnog ponašanja koje, barem delom, potiče iz nerazumevanja sopstvenih osećanja, a nekada i kao reakcija na to. $U$ nekim terapeutskim pristupima se kao tretman aleksitimije preporučuje rad na povećanju fleksibilnog preusmeravanja pažnje između telesnih senzacija, spoljnih senzornih signala u datom kontekstu i sopstvenih uverenja i očekivanja i uzrocima i značenjima senzacija (Duquette, 2020).

Dalje, rezultati ovog istraživanja rasvetljavaju i ulogu mračnih crta koje su okarakterisane kao relativno adaptivne i orijentisane na delotvornost. lako su ove crte periferne i ne obuhvataju ono što čini mračno jezgro (npr. Dinić et al., 2021b), njihova uloga je evidentna u predikciji manjeg distresa. $S$ druge strane, iako su neke crte obuhvaćene faktorom antagonizma povezane sa distresom (npr. makijavelistički i narcistički antagonizam), njihova uloga u objašnjenju distresa je manja. Moguće je da je uloga ovih centralnih, antagonističkih crta Mračne tetrade više indikativna za odnos prema drugima i eksternalne probleme, poput agresije i zloupotrebe supstanci (npr. Muris et al., 2017). Naime, prethodno istraživanje pokazuju da su dominantni korelati mračnih crta sklonost ka rizičnim ponašanjima, a ne loše blagostanje, prisustvo internalizovanih simptoma i drugi aspekti mentalnog zdravlja i distresa (Dinić et al., 2020a).

Postoji nekoliko ograničenja ovog istraživanja. Prvo se ogleda u uzorku koji je prigodan i koga većinom čine pripadnice ženskog pola i mlađi ispitanici (pretežno studenti). S obzirom na to, generalizabilnost rezultata je ograničena. Drugo, neke skale korišćene u ovom istraživanju imaju marginalnu pouzdanost (npr. makijavelističko planiranje i eksterno orijentisano razmišljanje), a korišćeni instrumenti FFNI i FFMI iako su bazirani na savremenim koncepcijama mračnih crta kao multidimenzionalnim konstruktima, i dalje su u procesu validacije. Ipak, niža pouzdanost npr. eksterno orijentisanog mišljenja je i osnovna kritika upućena TAS-20 (npr. Meganck et al., 2008). Treće, rezultati su bazirani na merama samoprocene, a moguće je da samoprocena aleksitimije ne prati i uspešnost u zadacima prepoznavanja emocija. Na primer, u jednom istraživanju je pokazano da ukupan skor na TAS-20 skali nije ostvario značajnu korelaciju sa zadatkom 
zauzimanja tuđe perspektive u opisu situacije (Lockwood et al., 2013). Četvrto, primenjen nacrt u ovom istraživanju ne dozvoljava zaključivanje o kauzalnom odnosu, te bi longitudinalni nacrt pružao jasniji uvid $u$ ispitivane medijacione odnose. Na kraju, dodatni uvid u odnos mračnih crta i aleksitimije bi se dobio ispitanjem na kliničkoj populaciji.

Sumirano, rezultati pokazuju da su ključni prediktori svih faktora aleksitimije i opšteg distresa sekundarna psihopatija u pozitivnom i makijavelistička delotvornost u negativnom smeru, odnosno periferne mračne crte koje ne ulaze sržni, antagonistički faktor mračnih crta, već u faktor delotvornosti. Mračnim crtama je najviše objašnjen faktor aleksitimije koji se odnosi na poteškoće u opisivanju emocija, a ovaj faktor je i jedini značajan medijator u odnosu između mračnih crta i distresa. Moglo bi se zaključiti da su glavni prediktori aleksitimije među mračnim crtama facete koje se odnose na slabu kontrolu impulsa, pasivnost, doživljaj nekompetentnosti, nisko samopouzdanje i vulnerabilnost, te da se ove karakteristike povezuju s većim distresom zbog nerazumevanja sopstvenih emocionalnih stanja. Budući da aleksitimija obuhvata primarno kognitivni aspekt emocionalnih deficita, moguće je da bi afektivni aspekt emocionalnih deficita bio više u vezi sa antagonističkim aspektima mračnih crta, što je pokazano u ranijim istraživanjima (Dinić et al., 2020b; 2021b). lako u manjoj meri, centralni i antagonistički aspekti mračnih crta doprinose objašnjenju poteškoća prilikom opisivanja osećanja i eksterno orijentisanog mišljenja.

\section{Sukob interesa}

Nemamo sukob interesa za prijavljivanje.

Izjava o dostupnosti podataka

Podaci su dostupni na lični zahtev kontaktiranjem autora rada.

\section{Napomena}

Deo rezultata je prikazan u master radu Cmiljanić, A. (2020). Relacija crta Mračne tetrade i aleksitimije. Nepublikovan master rad, Filozofski fakultet, Univerzitet u Novom Sadu. 


\section{Literatura}

Ackerman, R. A., Witt, E. A., Donnellan, M. B., Trzesniewski, K. H., Robins, R. W., \& Kashy, D. A. (2011). What does the Narcissistic Personality Inventory really measure? Assessment, 18(1), 67-87. https://doi.org/10.1177/1073191110382845

Bagby, M. R., Parker, J., \& Taylor, G. J. (1994) The twenty-item Toronto Alexithymia scale-I. Item selection and cross-validation of the factor structure. Journal of Psychosomatic Research, 38(1), 23-32. https://doi.org/10.1016/00223999(94)90005-1

Birkás, B., Pátkai, G., \& Csathó, Á. (2020). The Mediating Role of the Dark Triad Between Life History Strategy and Perceived Stress Factors.

Psychological Reports, 123(2), 252-265.

https://doi.org/10.1177/0033294118818095

Book, A., Visser, B. A., Blais, J., Hosker-Field, A., Methot-Jones, T., Gauthiera, N. Y., Volk, A., Holden, R. R., \& D'Agata, M. T. (2016). Unpacking more "evil": What is at the core of the dark tetrad? Personality and Individual Differences, 90, 269-272. https://doi.org/10.1016/.j.paid.2015.11.009

Burghart, M., \& Mier, D. (2021, May 14). No feelings for me, no feelings for you: A meta-analysis on alexithymia and empathy in psychopathy. PsyArXiv Preprints. https://doi.org/10.31234/osf.io/v2e8g

Cairncross, M., Veselka, L., Schermer, J. A., \& Vernon, P. A. (2013) A Behavioral Genetic Analysis of Alexithymia and the Dark Triad Traits of Personality. Twin Research and Human Genetics, 16(3), 690-697. https://doi.org/10.1017/thg.2013.19

Chabrol, H., Van Leeuwen, N., Rodgers, R., \& Séjourné, N. (2009). Contributions of psychopathic, narcissistic, Machiavellian, and sadistic personality traits to juvenile delinquency. Personality and Individual Differences, 47(7), 734739. https://doi.org/10.1016/i.paid.2009.06.020

Chen, J., Xu, T., Jing, J., \& Chan, R.C.K. (2011). Alexithymia and emotional regulation: A cluster analytical approach. BMC Psychiatry, 11(1), 1-6. https://doi.org/10.1186/1471-244X-11-33

Cmiljanić, A. i Rokvić, N. (2018) Odnos aleksitimije sa psihološkim distresom i pozitivnim i negativnim afektom u studentskoj populaciji. Rad prezentovan na 66. Kongresu psihologa Srbije: Futurizam u psihologiji psihologija u zoni budućeg razvoja, Zlatibor, Srbija. 
Coleman, S., Pincus, A. L., \& Smyth, J. M. (2018). Narcissism and stress-reactivity: A biobehavioural health perspective. Health Psychology Review, 13(1), 35-72. https://doi.org/10.1080/17437199.2018.1547118

Collison, K. L., Vize, C. E., Miller, J. D., \& Lynam, D. R. (2018). Development and preliminary validation of a five factor model measure of Machiavellianism. Psychological Assessment, 30(10), 1401-1407. https://doi.org/10.1037/pas0000637

Del Gaizo, A. L., \& Falkenbach, D. M. (2008). Primary and secondary psychopathic-traits and their relationship to perception and experience of emotion. Personality and Individual Differences, 45(3), 206-212. https://doi.org/10.1016/j.paid.2008.03.019

Dinić, B. (2019). Principi psihološkog testiranja. Filozofski fakultet u Novom Sadu. Preuzeto sa http://digitalna.ff.uns.ac.rs/sites/default/files/db/books/97886-6065-540-2.pdf

Dinić, B. M., \& Jevremov, T. (2019). Trends in research related to the Dark Triad: A bibliometric analysis. Current Psychology. Online first. https://doi.org/10.1007/s12144-019-00250-9

Dinić, B. M., \& Vujić, A. (2019). The Pathological Narcissism Inventory: Measurement invariance across Serbian and USA samples and further validation. European Journal of Psychological Assessment, 36, 670-680. https://doi.org/10.1027/1015-5759/a000537

Dinić, B. M., Bullut Allred, T. Petrović, B., \& Wertag, A. (2020c). A test of three sadism measures. Short Sadistic Impulse Scale, Varietes of Sdistic Tendencies, and Assessment of Sadistic Personality. Journal of Individual Differences. Online First. https://doi.org/10.1027/1614-0001/a000319

Dinić, B. M., Sadiković, S., \& Wertag, A. (2020a). Factor mixture analysis of the Dark Triad and Dark Tetrad. Could sadism make a difference? Journal of Individual Differences. Online First. https://doi.org/10.1027/16140001/a000331

Dinić, B. M., Sokolovska, V., \& Tomašević, A. (2021a). The narcissism network and centrality of narcissism features. Current Psychology. Online First. https://doi.org/10.1007/s12144-020-01250-w

Dinić, B. M., Wertag, A., Sokolovska, V., \& Tomašević, A. (2020b). Centrality and redundancy of the Dark Tetrad traits. Personality and Individual Differences, 155. Online first. https://doi.org/10.1016/.jpaid.2019.109621 
Dinić, B. M., Wertag, A., Sokolovska, V., \& Tomašević, A. (2021b). The good, the bad, and the ugly: Revisiting the Dark Core. Current Psychology. Online First. https://doi.org/10.1007/s12144-021-01829-x

Duquette, P. (2020). More Than Words Can Say: A Multi-Disciplinary Consideration of the Psychotherapeutic Evaluation and Treatment of Alexithymia. Frontiers in Psychiatry, 11, 433. https://doi.org/10.3389/fpsyt.2020.00433

Furnham, A., Richards, S. C., \& Paulhus, D. L. (2013). The Dark Triad of Personality: A 10Year Review. Social and Personality Psychology Compass, 7(3), 199216. https://doi.org/10.1111/spc3.12018

Garofalo, C., Virgilio, C., Bogaerts, S., \& Schimmenti, A. (2019). Dark ladies: Maladaptive personality domains, alexithymia, and the dark triad in women. Clinical Neuropsychiatry: Journal of Treatment Evaluation, 16(5-6), 221-228. https://doi.org/10.36131/clinicalnpsych2019050605

Glover, N., Miller, J. D., Lynam, D. R., Crego, C., \& Widiger, T. A. (2012). The FiveFactor Narcissism Inventory: A Five-Factor Measure of Narcissistic Personality Traits. Journal of Personality Assessment, 94(5), 500-512. https://doi.org/10.1080/00223891.2012.670680

Goerlich, K. S. (2018) The Multifaceted Nature of Alexithymia - A Neuroscientific Perspective. Frontiers in Psychology, 9, 1614. https://doi.org/10.3389/fpsyg.2018.01614

Grover, S., \& Furnham, A. (2021). Does emotional intelligence and resilience moderate the relationship between the Dark Triad and personal and work burnout? Personality and Individual Differences, 169, 109979. https://doi.org/10.1016/j.paid.2020.109979

Hayes, A. F. (2017). Introduction fo mediation, moderaton, and conditional process analysis: A regression-nased approach ( $2^{\text {nd }}$ ed.). Guilford Press.

Heym, N., Firth, J., Kibowski, F., Sumich, A., Egan, V., \& Bloxsom, A. J. (2019). Empathy at the Heart of Darkness: Empathy Deficits That Bind the Dark Triad and Those That Mediate Indirect Relational Aggression. Frontiers in Psychiatry, 10, 95. https://doi.org/10.3389/fpsyt.2019.00095

IBM Corp. (2015). IBM SPSS Statistics for Windows, Version 23.0. Armonk, NY: IBM Corp.

JASP Team (2020). JASP (Version 0.14.1) [Computer software]. 
Jonason, P., \& Krause, L. (2013). The emotional deficits associated with the Dark Triad traits: Cognitive empathy, affective empathy, and alexithymia. Personality and Individual Differences, 55, 532-537. https://doi.org/10.1016/i.paid.2013.04.027

Jordan, K. D., \& Smith, T. W. (2017). The interpersonal domain of alexithymia. Personality and Individual Differences, 110, 65-69. https://doi.org/10.1016/j.paid.2017.01.027

Jovanović, V., Gavrilov-Jerković, V., Žuljević, D. i Brdarić, D. (2014). Psihometrijska evaluacija Skale depresivnosti, anksioznosti i stresa-21 (DASS-21) na uzorku studenata u Srbiji. Psihologija, 4711), 93-112. https://doi.org/10.2298/PSI1401093J

Karukivi, M., \& Saarijärvi, S. (2014). Development of alexithymic personality features. World Journal of Psychiatry, 4(4), 91-102. https://doi.org/10.5498/wjp.v4.14.91

Kaufman, S. B., Weiss, B., Miller, J. D., \& Campbell, W. K. (2020). Clinical Correlates of Vulnerable and Grandiose Narcissism: A Personality Perspective. Journal of Personality Disorders, 34(1), 107-130. https://doi.org/10.1521/pedi_2018_32_384

Kim J. H. (2019). Multicollinearity and misleading statistical results. Korean Journal of Anesthesiology, 72(6), 558-569. https://doi.org/10.4097/kja.19087

Koehn, M. A., Okan, C., \& Jonason, P. K. (2019). A primer on the Dark Triad traits. Australian Journal of Psychology, 71(1), 7-15. https://doi.org/10.1111/ajpy.12198

Kückelhaus, B. P., Blickle, G., Kranefeld, I., Körnig, T., \& Genau, H.A. (2021). Five Factor Machiavellianism: Validation of a New Measure. Journal of Personality Assessment, 103(4), 509-522. https://doi.org/10.1080/00223891.2020.1784182

Lander, G. C., Lutz-Zois, C. J., Rye, M. S., \& Goodnight, J. A. (2012). The differential association between alexithymia and primary versus secondary psychopathy. Personality and Individual Differences, 52(1), 45-50. https://doi.org/10.1016/i.paid.2011.08.027

Levenson, M. R., Kiehl, K. A., \& Fitzpatrick, C. M. (1995). Assessing psychopathic attributes in a noninstitutionalized population. Journal of Personality and Social Psychology, 68(1), 151-158. https://doi.org/10.1037/0022-3514.68.1.151 
Lockwood, P. L., Bird, G., Bridge, M., \& Viding, E. (2013). Dissecting empathy: High levels of psychopathic and autistic traits are characterized by difficulties in different social information processing domains. Frontiers in Human Neuroscience, 7, 760. https://doi.org/10.3389/fnhum.2013.00760

Louth, S.M., Hare, R.D., \& Linden, W. (1998). Psychopathy and alexithymia in female offenders. Canadian Jurnal of Behavioural Scinece, 30, 91-98. https://doi.org/10.1037/h0085809

Lovibond, P. F., \& Lovibond S. H. (1995). The structure of negative emotional states: Comparison of the Depression Anxiety Stress Scale (DASS) with the Beck Depression and Anxiety Inventories. Behaviour Research and Therapy, 33(3), 335-343. https://doi.org/10.1016/0005-7967(94)00075-U

Meganck, R., Vanheule, S., \& Desmet, M. (2008). Factorial validity and measurement invariance of the 20 -item Toronto Alexithymia Scale in clinical and nonclinical samples. Assessment, 36-47. https://doi.org/10.1177/1073191107306140

Miller, J. D., Few, L. R., Wilson, L., Gentile, B., Widiger, T. A., MacKillop, J., \& Keith Campbell, W. (2013). The Five-Factor Narcissism Inventory (FFNI): A test of the convergent, discriminant, and incremental validity of FFNI scores in clinical and community samples. Psychological Assessment, 25(3), 748758. https://doi.org/10.1037/a0032536

Miller, J. D., Vize, C., Crowe, M. L., \& Lynam, D. R. (2019). A Critical Appraisal of the Dark-Triad Literature and Suggestions for Moving Forward. Current Directions in Psychological Science, 28(4), 353360. https://doi.org/10.1177/0963721419838233

Mojsa-Kaja, J., Szklarczyk, K., Gonzelez-Yubero, S., \& Palomera, R. (2021). Cognitive emotion regulation strategies mediate the relationship between Dark Triad traits and negative emotional states experienced during the COVID-19 pandemic. Personality and Individual Differences, 181. Online First. https://doi.org/10.1016/j.paid.2021.111018

Muris, P., Merckelbach, H., Otgaar, H., \& Meijer, E. (2017). The Malevolent Side of Human Nature: A Meta-Analysis and Critical Review of the Literature on the Dark Triad (Narcissism, Machiavellianism, and Psychopathy). Perspectives on Psychological Science, 12(2), 183-204. https://doi.org/10.1177/1745691616666070

Murphy, J., Wulff, K., Catmur, C., \& Bird, G. (2018). Alexithymic traits, independent of depression and anxiety, are associated with reduced sleep quality. 
Personality and Individual Differences, 129, 175-178. https://doi.org/10.1016/i.paid.2018.03.023

Nekouei, Z. K., Doost, H. T., Yousefy, A., Manshaee, G., \& Sadeghei, M. (2014). The relationship of Alexithymia with anxiety-depression-stress, quality of life, and social support in Coronary Heart Disease (A psychological model). Journal of Education and Health Promotion, 3:68. https://doi.org/10.4103/2277-9531.134816

Papageorgiou, K. A., Denovan, A., Dagnall, N., \& Artamonova, E. (2021). A crosscultural investigation of the Five-Factor Narcissism Inventory short form: Narcissism as a multidimensional trait in the United Kingdom and Russia. Journal of Personality Assessment. Advance online publication. https://doi.org/10.1080/00223891.2021.1929263

Paulhus, D. L. (2014). Toward a Taxonomy of Dark Personalities. Current Directions in Psychological Science, 23(6), 421-426. https://doi.org/10.1177/0963721414547737

Paulhus, D. L., \& Williams, K. M. (2002). The Dark Triad of personality: Narcissism, Machiavellianism, and psychopathy. Journal of Research in Personality, 36, 556-563. https://doi.org/10.1016/S0092-6566(02)00505-6

Pham, T. H., Ducro, C., \& Luminet, O. (2010). Psychopathy, Alexithymia and emotional intelligence in aforensic hospital. International Journal of Forensic Mental Health, 9(1), 24-32. https://doi.org/10.1080/14999013.2010.484641

Plouffe, R. A., Saklofske, D. H., \& Smith, M. M. (2017). The Assessment of Sadistic Personality: Preliminary psychometric evidence for a new measure. Personality and Individual Differences, 104, 166-171. https://doi.org/10.1016/i.paid.2016.07.043

Puthillam, A., Karandikar, S., \& Kapoor, H. (2019). I see how you feel: How the dark triad recognizes emotions. Current Psychology. Online First. https://doi.org/10.1007/s12144-019-00359-x

Rauthmann, J. F., \& Kolar, G. P. (2012). How “dark" are the Dark Triad traits? Examining the perceived darkness of narcissism, Machiavellianism, and psychopathy. Personality and Individual Differences, 53(7), 884-889. https://doi.org/10.1016/j.paid.2012.06.020

Revelle, W. (2020). psych: Procedures for Psychological, Psychometric, and Personality Research. Northwestern University, Evanston, Illinois. R 
package version 2.0.7. Preuzeto sa: https://CRAN.Rproject.org/package $=$ psych

Ridings, L. E., \& Lutz-Zois, C. J. (2014). Emotional dysregulation and borderline personality disorder: Explaining the link between secondary psychopathy and alexithymia. Personality and Individual Differences, 57, 14-19. https://doi.org/10.1016/j.paid.2013.09.008

Rogoza, R., Cieciuch, J., Strus, W., \& Kłosowski, M. (2020). Investigating the Structure of the Polish Five Factor Narcissism Inventory: Support for the Three-Factor Model of Narcissism. Psychological Assessment. Advance online publication. http://dx.doi.org/10.1037/pas0000901

Schimmenti, A., Jonason, P. K., Passanisi, A., Marca, L. L., Dio, N. D., \& Gervasi, A. M. (2019). Exploring the Dark Side of Personality: Emotional Awareness, Empathy, and the Dark Triad Traits in an Italian Sample. Current Psychology, 38, 100-109. https://doi.org/10.1007/s12144-017-9588-6

Sherman, E. D., Miller, J. D., Few, L. R., Campbell, W. K., Widiger, T. A., Crego, C., \& Lynam, D. R. (2015). Development of a Short Form of the Five-Factor Narcissism Inventory: The FFNI-SF. Psychological Assessment, 27(3), 11101116. https://doi.org/10.1037/pas0000100

Tabachnick, B. G., \& Fidell, L. S. (2019). Using multivariate statistics (7th ed.). Pearson.

Takamatsu, R., \& Takai, J. (2017). With or Without Empathy: Primary Psychopathy and Difficulty in Identifying Feelings Predict Utilitarian Judgment in Sacrificial Dilemmas. Ethics \& Behavior, 29(1), 71-85. https://doi.org/10.1080/10508422.2017.1367684

Taylor, G. J. (2000). Recent Developments in Alexithymia Theory and Research. The Canadian Journal of Psychiatry, 45(2), 134-142. https://doi.org/10.1177/070674370004500203

Taylor, G. J., \& Bagby, R. M. (2013). Psychoanalysis and empirical research: The example of alexithymia. Journal of the American Psychoanalytic Association, 67(1), 99-133. https://doi.org/10.1177/0003065112474066

Trajanović, N., Đurić, V., Latas, M., Milovanović, S., Jovanović, A., \& Đurić, D. (2013). Serbian translation of the 20 -item toronto alexithymia scale: Psychometric properties and the new methodological approach in translating scales. Srpski arhiv za celokupno lekarstvo, 14(1), 366-370. https://doi.org/10.2298/SARH1306366T 
Velotti, P., Garofalo, C., Petrocchi, C., Cavallo F., Popolo, R., \& Dimaggio G. (2016). Alexithymia, emotion dysregulation, impulsivity and aggression: $A$ multiple mediation model. Psychiatric Research, 237, 296-303.

https://doi.org/10.1016/.jpsychres.2016.01.025

\section{Relationships between the Dark Tetrad, alexithymia, and distress: Analysis at the facet level and level of antagonistic and agentic factors of dark traits}

Bojana M. Dinić1 (iD), Anđela Cmiljanić1 and Nikola Rokvić (iD

${ }^{1}$ Department of Psychology, Faculty of Philosophy, University of Novi Sad

${ }^{2}$ Faculty of Law and Business Studies, Dr Lazar Vrkatic, Union University

\section{ABSTRACT}

The main goal of this research is to determine the relationship between the Dark Tetrad traits and the alexithymia factors, taking into account the multidimensional nature of the dark lines, as well as their antagonistic (maladaptive) aspects and agency aspects (more adaptive aspects). Additionally, the mediator role of the alexithymia factors in the relationship between the dark traits and distress was examined. On a sample of 355 participants $(71.3 \%$ female) from the general population, the following instruments were used: Twenty-Item Toronto Alexithymia Scale (TAS-20), Depression Anxiety Stress Scale (DASS-21), Levenson Self-Report Psychopathy Scales (LSRP), Five Factor Machiavellianism Inventory (FFMI), Short Form of the Five-Factor Narcissism Inventory (FFNI-SF), and Assessment of Sadistic Personality (ASP). The results showed that dark traits and alexithymia factors shared $56 \%$ of the common variance, and that the main predictors of alexithymia are secondary psychopathy in the positive direction and Machiavellian agency in the negative direction, followed by the narcissistic antagonism and primary psychopathy, both in a positive direction. The results showed that the factor od dark traits that contains agentic characteristics at 
the positive pole had a higher and negative contribution in explaining alexithymia and distress, compared to the factor that contains primarily antagonistic features. The most explained factor of alexithymia based on dark traits is factor that refers to problems in the identification of emotions, and this factor is also a solely significant mediator in the prediction of distress based on alsmost all facets and both factors of Dark Tetrad traits. Thus, mainly antagonistic dark traits are positively related to distress because of higher emotional deficits in indentification of emotions, while dark traits which more refer to agency are negatively related to distres because of lower emotional deficits.

Key words: Dark Tetrad, Dark Triad, antagonism, agency, alexithymia, distress 


\section{Prilog A}

Korelacije između faceta i faktora crta Mračne tetrade

\begin{tabular}{cccccccccc}
\hline & PS & SS & S & Mant & Mdel & Mpla & Nant & Neks & Nneu \\
\hline PS & 1 & & & & & & & & \\
SS & .33 & 1 & & & & & & & \\
S & .45 & .18 & 1 & & & & & & \\
Mant & .65 & .31 & .35 & 1 & & & & & \\
Mdel & .11 & -.49 & .08 & .15 & 1 & & & & \\
Mpla & -.12 & -.36 & -.02 & .00 & .16 & 1 & & \\
Nant & .68 & .40 & .49 & .68 & .14 & -.11 & 1 & & \\
Neks & .34 & .06 & .24 & .36 & .54 & .05 & .52 & 1 & \\
Nneu & -.11 & .34 & -.001 & -.13 & -.58 & .01 & .04 & -.09 & 1 \\
\hline
\end{tabular}

Legenda: PS = primarna psihopatija, SS = sekundarna psihopatija, S = sadizam, Mant $=$ makijavelistički antagonizam, Mdel = makijavelistička delotvornost, Mpla = makijavelističko planiranje, Nant $=$ narcistički antagonizam, Neks $=$ narcistička ekstraverzija, Nneu = narcistički neuroticizam

Napomena: Korelacije $>+/-.11$ su značajne na nivou $p<.05$ 